\title{
Water Exchange and Spatial Distribution of Hg in Jiaozhou Bay
}

\author{
Dongfang Yang ${ }^{1,2, a}$, Zhenqing Miao, b, c, Haixia Li ${ }^{1}$, Xiaolong Zhang1, Qi Wang ${ }^{1}$ \\ ${ }^{1}$ Accountancy Shool, Xijing University, Xian 710123, China \\ ${ }^{2}$ North China Sea Environmental Monitoring Center, SOA, Qingdao 266033, China \\ ${ }^{3}$ College of Fisheries, Zhejiang Ocean University, Zhoushan, 316022, China \\ adfyang_dfyang@126.com, ${ }^{\mathrm{b}}$ corresponding author, 'mzq@zjou.edu.cn
}

Keywords: Hg; Water exchange; Source; Distribution; Peak surface; Jiaozhou Bay.

\begin{abstract}
This paper analyzed the influence of water exchange on spatial distribution of $\mathrm{Hg}$ in Jiaozhou Bay China based on investigation data on Hg in surface waters in April, July and October 1988. Results showed that $\mathrm{Hg}$ contents in surface waters in April, July and October 1988 were

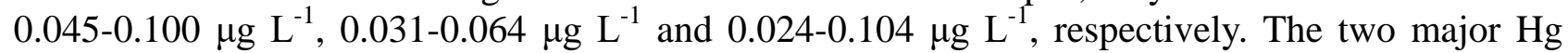
sources in Jiaozhou Bay were overland runoff and river flow, whose source strengths were 0.068-0.104 $\mu \mathrm{g} \mathrm{L}^{-1}$ and 0.061-0.074 $\mu \mathrm{g} \mathrm{L}^{-1}$, respectively. A block diagram model was provided to reveal the changing of $\mathrm{Hg}$ contents during migration processes, i.e., human emission, overland transport, river flow transport and oceanic transport. Hg in Jiaozhou Bay was mainly input from major sources located in the west, north and east of the bay, and $\mathrm{Hg}$ contents in the bay were relative high. However, $\mathrm{Hg}$ contents in the open waters were still relative low. Hence, by means of water exchange, there was a equivalent peak surface $\left(0.050 \mu \mathrm{g} \mathrm{L}^{-1}\right)$ in the bay. These findings were showing the influence of water exchange on $\mathrm{Hg}$ contents in this semi-closed bay.
\end{abstract}

\section{Introduction}

Hg has been widely used in industries of chlor-alkali, plastics, battery and electronics etc. However, the rapid development of industry results in $\mathrm{Hg}$ pollution in the air, soil and water, and marine bays since ocean is the sink of various pollutants [1-7]. Hg is also one of the critical poisonous heavy metal elements, and therefore it is necessary to understanding the migration processes of $\mathrm{Hg}$ in marine bays [8-11]. Jiaozhou Bay is a semi-closed bay located in Shandong Province, eastern China. This paper analyzed the influence of water exchange on spatial distribution of $\mathrm{Hg}$ in Jiaozhou Bay China based on investigation data on $\mathrm{Hg}$ in surface waters in April, July and October 1988, and to provide basis for the research and pollution control countermeasures.

\section{Study area and data collection}

\subsection{Study area}

Jiaozhou Bay is located in the south of Shandong Province, eastern China $\left(35^{\circ} 55^{\prime}-36^{\circ} 18^{\prime} \mathrm{N}\right.$, $120^{\circ} 04^{\prime}-120^{\circ} 23^{\prime} \mathrm{E}$ ), and is connected to the Yellow Sea in the south. The total area and average water depth are $446 \mathrm{~km} 2$ and $7 \mathrm{~m}$, respectively, yet the width of the bay mouth was only $3 \mathrm{~km}$. This bay is a semi-closed bay. There are a dozen of rivers including Dagu River, Haibo Rriver, Licun Rriver, and Loushan Rriver etc., all of which are seasonal rivers [12-13].

\subsection{Data collection}

The investigation on Hg in surface waters in Jiaozhou Bay was carried on in in April, July and October 1988. There were 13 sampling sites in April and July 1988 (i.e., 31, 32, 33, 34, 35, 36, 84, 85, 86, 87, 88, 89 and 90), and were 6 sampling sites in October 1988 (i.e., 84, 85, 86, 87, 88 and 89) (Fig. 1). Hg in surface waters was sampled and monitored follow by National Specification for Marine Monitoring [14]. 


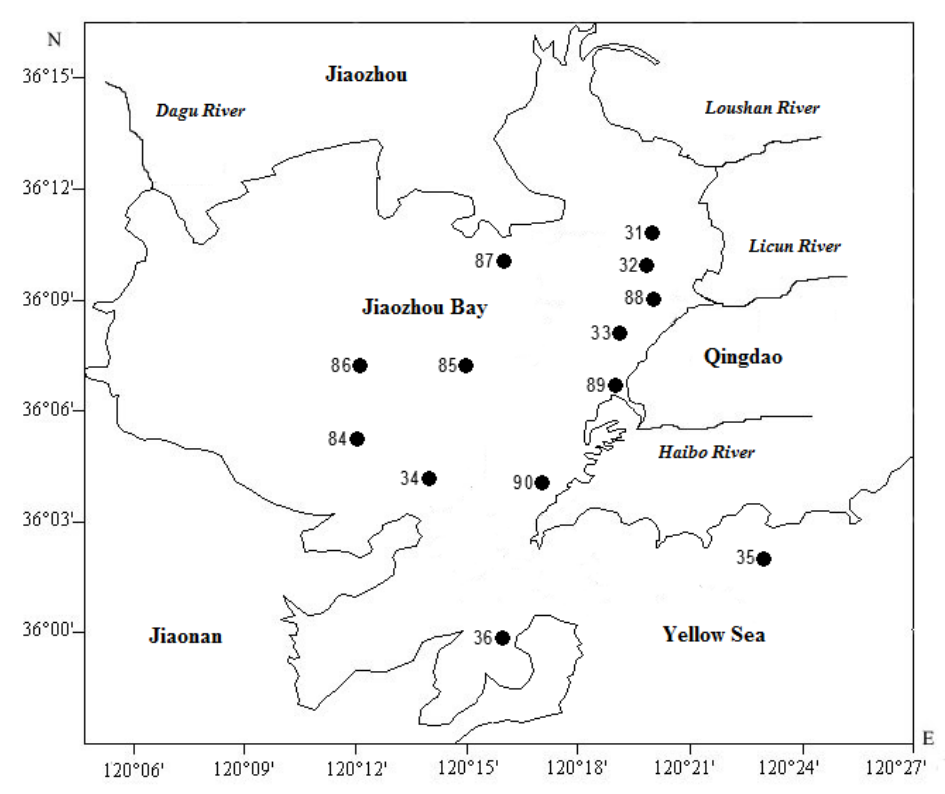

Fig.1 Geographic location of Jiaozhou Bay and sampling sites

\section{Results and discussion}

\subsection{Contents and pollution levels of $\mathrm{Hg}$}

$\mathrm{Hg}$ contents in surface waters in April, July and October 1988 were 0.045-0.100 $\mu \mathrm{g} \mathrm{L-1,}$ 0.031-0.064 $\mu \mathrm{g} \mathrm{L-1}$ and 0.024-0.104 $\mu \mathrm{g}$ L-1, respectively. In according to Guidelines for $\mathrm{Hg}$ in Sea Water Quality Standard (GB3097-1997) (Table 1), the pollution level of Hg in surface waters in different months in 1988 were generally ranging from Class I to III. In April 1988, high values of Hg contents were in Sites of 32, 33, 84, 86, 87, 89 and 90, in where Hg contents were 0.050-0.100 $\mu \mathrm{g} \mathrm{L}-1$ and were belong to Class II to III, yet in the bay center, bay mouth and open waters were lower than $0.050 \mu \mathrm{g} \mathrm{L-1}$ and were belong to Class I. In July 1988, high values of Hg contents were in Sites of 33, 89 and 90 in the estuary of Haibo River, in where Hg contents were 0.053-0.064 $\mu \mathrm{g}$ L-1 and were belong to Class II to III, while in other positions were lower than $0.050 \mu \mathrm{g} \mathrm{L-1}$ and were belong to Class I. In October 1988, high values of Hg contents were in Sites of 84, 86, 87 and 89, in where Hg contents were $0.068-0.104 \mu \mathrm{g} \mathrm{L-1}$ and were belong to Class II to III, while in the bay center and the northeast of the bay were lower than $0.050 \mu \mathrm{g} \mathrm{L}-1$ and were belong to Class I. In general, Hg contents in Jiaozhou Bay 1988 were showing seasonal and spatial variations, and the pollution level of $\mathrm{Hg}$ in surface waters in was slight to moderate.

Table 1 Guidelines for Hg in Sea Water Quality Standard (GB3097-1997)

\begin{tabular}{|c|c|c|c|}
\hline Class & I & II and III & IV \\
\hline $\mathrm{Pb}$ content $/ \mu \mathrm{g} \mathrm{L}^{-1}$ & 0.05 & 0.20 & 0.50 \\
\hline
\end{tabular}

\subsection{Horizontal distributions and sources of $\mathbf{H g}$}

In April 1988, high value of Hg contents was in Site 84 (0.100 $\mu \mathrm{g} \mathrm{L-1)}$, and the high value center was in the coastal waters in the southwest of the bay, and Hg contents were decreasing from the high value center to the bay mouth $(0.046 \mu \mathrm{g} \mathrm{L}-1)$ and the open waters $(0.045 \mu \mathrm{g} \mathrm{L}-1)$ (Fig. 2), this indicated that overland runoff was the major source in this position. The other high value of $\mathrm{Hg}$ contents was in Site 87 (0.080 $\mu \mathrm{g} \mathrm{L-1)}$ in April 1988, and the high value center was in the coastal waters in the northeast of the bay, and $\mathrm{Hg}$ contents were decreasing from the high value center to the bay mouth $(0.045 \mu \mathrm{g} \mathrm{L-1})$ (Fig. 2), this indicated that river flow was the major source in this position. The third high value of $\mathrm{Hg}$ contents was in Site $89(0.061 \mu \mathrm{g} \mathrm{L}-1)$ in April 1988, and the high value center was in the estuary of Haibo River, and $\mathrm{Hg}$ contents were decreasing from the high value center to the bay mouth $(0.045 \mu \mathrm{g} \mathrm{L-1)}$ (Fig. 2), this indicated that river flow was the major 
source in this position. In July 1988, high value of Hg contents was in Site $89(0.064 \mu \mathrm{g} \mathrm{L-1)}$ in the estuary of Haibo River, and the high value center was in the estuary of Haibo River, and $\mathrm{Hg}$ contents were decreasing from the high value center to the inner side of the bay mouth $(0.056 \mu \mathrm{g}$ L-1), the bay mouth $(0.040 \mu \mathrm{g} \mathrm{L}-1)$ and the open waters $(0.033 \mu \mathrm{g}$ L-1) (Fig. 3), this indicated that river flow was the major source in this position. In October1988, high value of Hg contents was in Site $86(0.104 \mu \mathrm{g} \mathrm{L}-1)$, and the high value center was in the coastal waters in the west of the bay, and $\mathrm{Hg}$ contents were decreasing from the high value center to the bay center $(0.024 \mu \mathrm{g} \mathrm{L-1)}$ (Fig. 4), this indicated that overland runoff was the major source in this position. The other high value of Hg contents was in Site 87 (0.068 $\mu \mathrm{g} \mathrm{L-1)}$ in October 1988, and the high value center was in the coastal waters in the northeast of the bay, and $\mathrm{Hg}$ contents were decreasing from the high value center to the center of the bay $(0.024 \mu \mathrm{g} \mathrm{L-1)}$ (Fig. 4), this indicated that river flow was the major source in this position. The third high value of Hg contents was in Site 89 (0.074 $\mu \mathrm{g} \mathrm{L-1)}$ in October 1988, and the high value center was in the estuary of Haibo River, and Hg contents were decreasing from the high value center to the center of the bay $(0.024 \mu \mathrm{g} \mathrm{L-1)}$ (Fig. 4$)$, this indicated that river flow was the major source in this position. In according to the horizontal distributions of $\mathrm{Hg}$ contents, it could be found that the two major Hg sources in Jiaozhou Bay were overland runoff and river flow, whose source strengths were 0.068-0.104 $\mu \mathrm{g} \mathrm{L-1}$ and 0.061-0.074 $\mu \mathrm{g} \mathrm{L-1,} \mathrm{respectively.}$

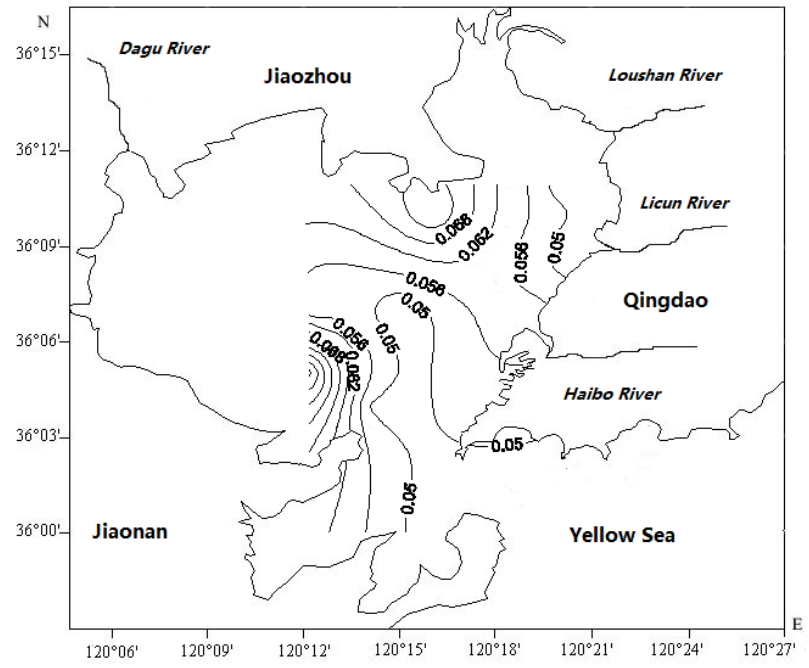

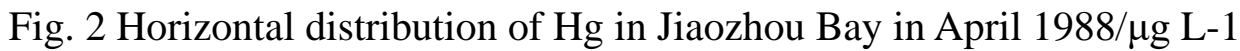

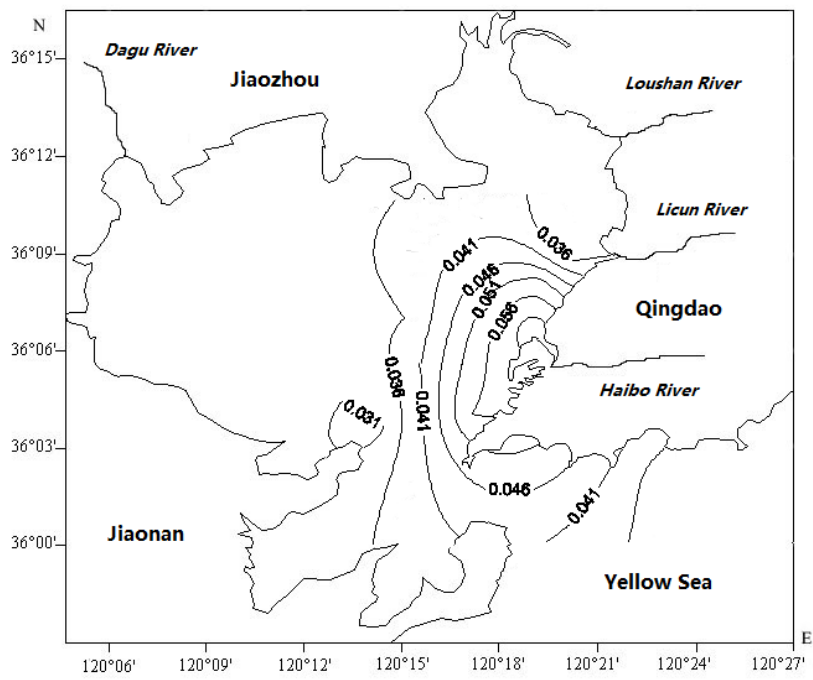

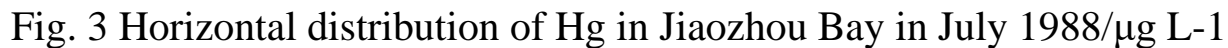




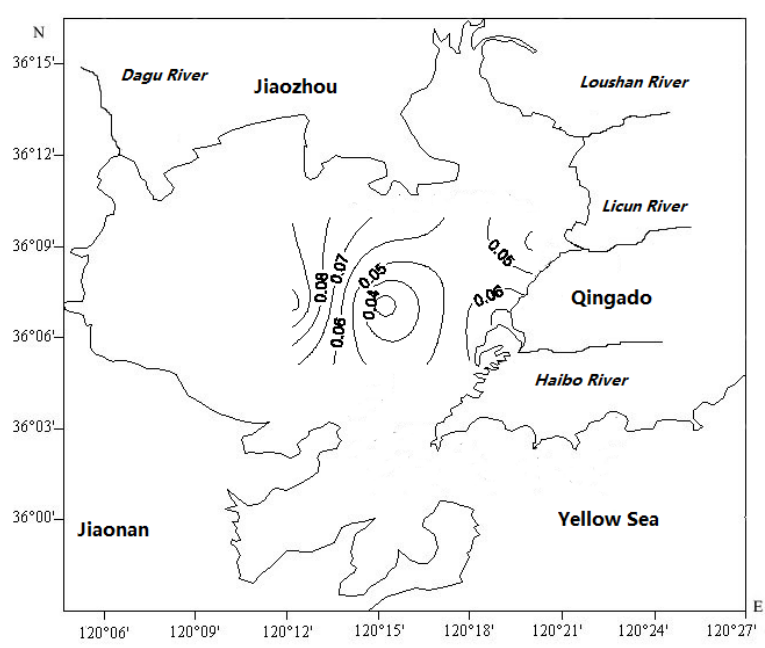

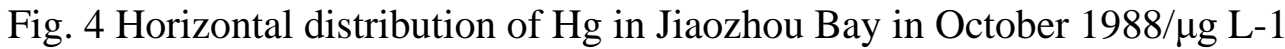

\subsection{Sourced input processes of $\mathrm{Hg}$}

Overland runoff and river flow were the two major Hg sources in Jiaozhou Bay, while the source strength of overland runoff was higher. This indicated the original source input of $\mathrm{Hg}$ to the land was relative high (0.068-0.104 $\mu \mathrm{g} \mathrm{L-1)}$, and the $\mathrm{Hg}$ contents were delivered to rivers by rainfall-runoff, and was diluted to a lower level (0.061-0.074 $\mu \mathrm{g} \mathrm{L}-1)$, and finally $\mathrm{Hg}$ contents were

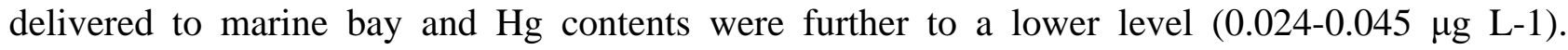
Jiaozhou Bay is a semi-closed bay which is surrounding by lands in the east, north, and west, and is connecting to open waters in the south via a narrow bay mouth. In generally, the major sources of Hg were all from land, while the sources were responsible in different seasons and positions. In April and October 1988, Hg in Jiaozhou Bay was mainly sourced from the west, north and east, and the source strength was 0.061-0.104 $\mu \mathrm{g}$ L-1. In July 1988 in Jiaozhou Bay, Hg in was mainly sourced from the east, and the source strength was $0.064 \mu \mathrm{g} \mathrm{L}-1$. The sourced input process of $\mathrm{Hg}$ could be described in a block diagram model (Fig. 5).

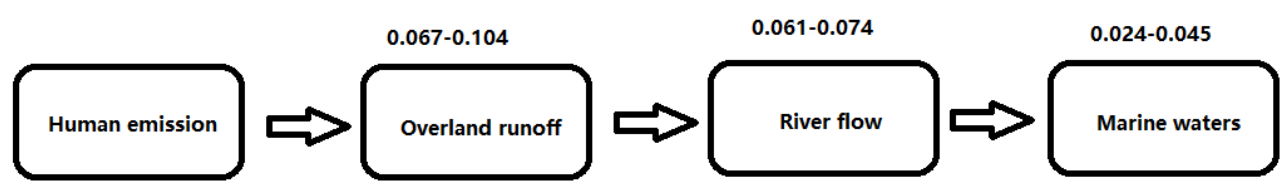

Fig. 5 Block diagram model of input processes of $\mathrm{Hg}$ in Jiaozhou Bay/ $\mu \mathrm{g} \mathrm{L}-1$

\subsection{Influence of water exchange on $\mathrm{Hg}$}

Marine bays are important palaces impacted by terrigenous matters, and the relevant researches were increasing [15-18]. The terrigenous matters input to Jiaozhou Bay included both anthropogenic and natural matters. Anthropogenic matters included organic matters, heavy metals and petroleum hydrocarbons, etc., while natural matters included silicates etc. [19-20]. By means of advection transport and dilute diffusion, the contents of these matters were changing continuously. Hence, understanding the water exchange and its influence on the matters in marine bay is essential and has been one of the research hotspots [21-22]. Due to the impact of terrigenous matters, the contents of the matters in waters inside Jiaozhou Bay were relative high, while in open waters were relative low. By means of water exchange, current with low matter contents in the open waters was transported into the bay, and current with high matter contents inside the bay was transported to the open waters. Hence, there was forming a equivalent peak surface in the bay along with the continuous water exchange. This equivalent peak surface was revealing the influence of marine current from the open waters to matter contents inside the bay, and the temporal changing of this 
equivalent surface was revealing the water exchange process. For instance, the contour line of $\mathrm{Hg}$ contents in April 1988 was demonstrating the instantaneous frames of $\mathrm{Hg}$ contents during the water exchange process (Fig. 6). Once marine current with low Hg content was invading to the bay and was encountering with waters with high $\mathrm{Hg}$ content inside the bay, the water exchange was proceeding, and was resulting in a semi-closed tongue-shaped contour line $(0.050 \mu \mathrm{g} \mathrm{L}-1)$ from the bay mouth to the center of the bay (Fig. 6). By means of this water exchange moving in cycles, $\mathrm{Hg}$ inside the bay was transported to the open waters via advection transport and dilute diffusion, and Hg contents in Jiaozhou Bay was decreasing continuously.

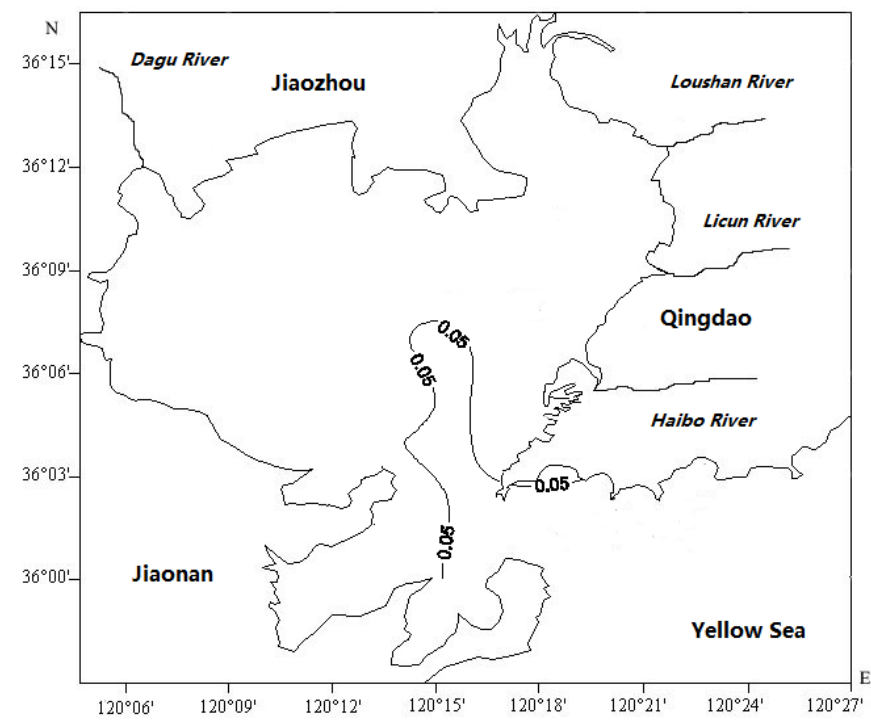

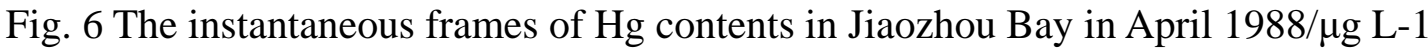

\section{Conclusion}

Hg contents in Jiaozhou Bay 1988 were showing seasonal and spatial variations, and the pollution level of $\mathrm{Hg}$ in surface waters in was slight to moderate. The two major $\mathrm{Hg}$ sources in Jiaozhou Bay were overland runoff and river flow, whose source strengths were 0.068-0.104 $\mu \mathrm{g} \mathrm{L-1}$ and 0.061-0.074 $\mu \mathrm{g} \mathrm{L}-1$, respectively.

The original source input of Hg to the land was relative high, and the Hg contents were delivered to rivers by rainfall-runoff, and was diluted to a lower level, and finally $\mathrm{Hg}$ contents were delivered to marine bay and $\mathrm{Hg}$ contents were further to a lower level. This sourced input process of $\mathrm{Hg}$ could be described in a block diagram model.

By means of water exchange, current with low matter contents in the open waters was transported into the bay, and current with high matter contents inside the bay was transported to the open waters. Hence, there was forming a equivalent peak surface in the bay along with the continuous water exchange.

\section{Acknowledgment}

This research was sponsored by the China National Natural Science Foundation (31560107), Doctoral Degree Construction Library of Guizhou Nationalities University and Research Projects of Guizhou Nationalities University ([2014]02), Research Projects of Guizhou Province Ministry of Education (KY [2014] 266), Research Projects of Guizhou Province Ministry of Science and Technology (LH [2014] 7376).

\section{References}

[1] Chen Y, Gao ZH, Qu YH, et al.: Chinese Journal of Oceanology Limnology, Vol. 25(2007), p. 455-458. (in Chinese) 
[2] Yang DF, Cao HR, Gao ZH, et al.: Ocean Environmental Science, Vol. 27 (2008), p. 37-39.

[3] Yang DF, Wang LL, Gao ZH, et al.: Ocean Environmental Science, Vol. 28 (2009), p. 501-505.

[4] Chen Y, Zhang YJ, Gao JH, et al.: Ocean Development and Management, Vol. 30 (2013), p. 81-83.

[5] Yang DF, Sun PY, Ju L, et al: Coastal Engineering, Vol. 32(2013), p.65-76.

[6] Yang DF, Xu ZJ Qu YF, et al.: Coastal Engineering, Vol. 33(2014), p. 67-78.

[7] Chen Y, Qu YF, Pei RL, et al.: Advanced Materials Research, Vol.955-959 (2014), p. 2491-2495.

[8] Yang DF, Zhu SX, Wang FY, et al.: Advanced Materials Research, Vol.955-959(2014), p. 2496-2500.

[9] Yang DF, Zhu SX, Wang FY, et al.: Applied Mechanics and Materials, Vol.556-562 (2014), p. 633-636.

[10] Yang DF, Wang FY, He HZ, et al.: Advanced Materials Research, Vols.955-959(2014), p. 1443-1447.

[11] Yang DF, Geng X, Qu YF, et al.: Ocean Development and Management, Vol. 31 (2014), p. 112-118. (in Chinese)

[12] Yang DF, Chen Y, Gao ZH, et al.: Chinese Journal of Oceanology and Limnology, Vol. 23(2005), p. 72-90. (in Chinese)

[13] Yang DF, Wang F, Gao ZH, et al. Marine Science, Vol. 28 (2004), p. 71-74. (in Chinese)

[14] China's State Oceanic Administration: The specification for marine monitoring (Ocean Press, Beijiang 1991), p.1-300. (in Chinese)

[15] Yang DF, Gao ZH, Cao HR, et al.: Coastal Engineering, Vol. 27 (2008), p. 65-71. (in Chinese)

[16] Yang DF, Gao ZH, Sun PY, et al.: Coastal Engineering, Vol. 28 (2009), p. 69-77. (in Chinese)

[17] Yang DF, Chen Y, Wu SY, et al.: Marine Science, Vol. 34 (2010), p. 52-56. (in Chinese)

[18] Yang DF, Miao ZQ, Ding ZR, et al.: Marine Science, Vol. 35 (2011), p. 112-116. (in Chinese)

[19] Yang DF and Miao ZQ: Marine Bay Ecology (I): Beijing, Ocean Precess, (2010), p. 1-320. (in Chinese)

[20] Yang DF and Gao ZH: Marine Bay Ecology (II): Beijing, Ocean Precess, (2010), p. 1-330. (in Chinese)

[21] Yang DF, Miao ZQ, Xu HZ, et al.: Marine Environmental Science, Vol. 32 (2013), p.373-380. (in Chinese)

[22] Yang DF, Wu YF, Wang L, et al.: 2014 IEEE workshop on electronics, computer and applications. Part C, 2014, p. 1008-1011. 